\title{
GENERATION DISPARITIES ON THE PERCEPTION OF SMEs BUSINESS RISKS
}

\author{
Zora Petráková \\ Faculty of Civil Engineering, Slovak University of Technology, Institute for Forensic Engineering, Bratislava, \\ Slovak Republic \\ Email: zora.petrakova@stuba.sk
}

\section{Karolina Okręglicka}

Faculty of Management, Czestochowa University of Technology, Czestochowa, Poland

Email: ka.okreglicka@gmail.com

\author{
Radim Maňák \\ University of Entrepreneurship and Law, Department of Entrepreneurship and Management, Ostrava, Czech \\ Republic \\ Email: radim.manak@vspp.cz \\ Vendula Fialová \\ University of Entrepreneurship and Law, Department of Entrepreneurship and Management, Ostrava, Czech \\ Republic \\ Email: vendula.fialova@vspp.cz
}

Received: 28 August 2021. Revision received: 12 November 2021. Accepted: 10 December 2021

\begin{abstract}
This article aims to identify common features, disparities, and consequences in the perception of business risks between generation X, Y, and Z entrepreneurs in the segment of small and medium-sized enterprises (SMEs). The empirical part of this research included the dataset of 1585 questionnaires fulfilled by the entrepreneurs from the SME segment from four Central European countries across 2019-2020. The disparities of the perception of business risks were analyzed using Chisquare and Kruskal-Wallis tests. The research results prove the existence of the significant disparities in the perception of the market, financial, personnel, legal, and operational risks sources by the entrepreneurs from X, Y, and Z generations. Generally, essential disparities are in the perception of business risks between generation $\mathrm{X}$ and Z. 61.7\% of SMEs from generation $\mathrm{X}$ believe that the number of possible requests for the specific products/services has a downward trend. In comparison, only $49.0 \%$ of SMEs from generation Z and $45.3 \%$ of SMEs from generation Y present the same opinion. The presented research results have the following implications: i. top management of SMEs should improve interpersonal relationships in the workplace; ii. fine-tuning of supporting programs by organizations supporting the business environment in the region of the Visegrad Group; iii. preparation of strategic documents dealing with the quality of the business environment or the training of top SME managers in the case of national policymakers.
\end{abstract}

KEYWORDS: SMEs, risk sources, disparities, age of entrepreneurs, assessment.

JEL CLASSIFICATION: M21, G32, L26.

Reference: Petrakova, Z., Okręglicka, M, Manak, R., \& Fialova, V. (2021). Generation disparities on the perception of SMEs business risks. International Journal of Entrepreneurial Knowledge, 9(2), 32-48. doi: 10.37335/ijek.v9i2.145

\section{INTRODUCTION}

Many research studies claim that companies reflect the characteristics and values of their top managers and owners (Aktas et al., 2016). As a result, a substantial diversity in business practices is taking place. Furthermore, recent financial studies (e.g. Neuberger \& Räthke-Döppner, 2015; Allee \& Yohn, 2009) highlight the effect of demographic characteristics (such as gender, age) of a top manager and behavioral 


\section{INTERNATIONAL JOURNAL OF ENTREPRENEURIAL KNOWLEDGE}

Issue 9, volume 2, ISSN 2336-2960 (Online)

www.ijek.org

traits (overconfidence, narcissism) on corporate decision-making (Belot \& Serve, 2018). However, the link between the characteristics of the top manager and financial decisions in the case of the small and medium-sized enterprises (SMEs) segment remains an insufficiently researched issue in the region of the Visegrad Group countries (hereinafter "V4 countries").

The demographic characteristics of top managers and owners are addressed in several ways: the internationalization of companies (Wach \& Glodowska, 2021); risk management (Crovini et al., 2021); entrepreneurial orientation (Kozubikova et al., 2015); leadership skills (Hubner et al., 2021); business decline experience (Dvorský et al., 2020) or innovation in the SME segment (Hock-Doepgen et al., 2021).

The originality of the article lies in the comprehensive analysis, assessment, and quantification of business risks in the SME segment in the business environment of the V4 countries with regard to the age of the parent manager or business owner. The sample of 1585 SMEs evaluates the differences and common features of the perception of selected sources of business risks based on primary research.

The article consists of five parts, which are logically connected. The theoretical basis is the area of risk management. This section is divided into subsections according to the types of business risks (market, financial, personnel, legal, operational risk, and business management). Scientific hypotheses are formulated separately for each section. The article's aim formulation, data collection information, and applied methods for scientific hypotheses evaluation and the demographic structure of respondents are described in the methodological section. Empirical results include findings of common and different characteristics of respondents' attitudes to selected types of business risks and the evaluation of the scientific hypotheses. Subsequently, the discussion consists of a summary of empirical results and a comparison of empirical studies that deal with the issue in the world. At the end of the article, the goal, the most important findings, the limits of the case study, the definition of primary and secondary users of the case study, and the formulation of other research directions and publishing activities of the authors are reformulated.

\section{THEORETICAL DEVELOPMENT OF THE SCIENTIFIC HYPOTHESES}

SMEs are sensitive to economic change (Hvolkova et al., 2016), suffer from a lack of capital and limited access to external capital (Rahman et al., 2018; Kersten et al., 2017; Baños-Caballero et al., 2016). They also do not have sufficient knowledge of business risk management and, as a result, poor quality human resource management. Pisar \& Bilkova (2019) claim that due to the lack of funds, SMEs face a shortage of quality and talented people. Ravselj \& Aristovnik (2018) emphasize the aspect of administrative and tax obstacles in the activities of SMEs. This is emphasized by the low financial performance of SMEs, which is reflected in the impossibility of hiring qualified professionals or outsourcing these services to an external entity.

Frantz et al. (2017) argue that strategic corporate governance depends on business owners, managers and leaders who think, analyze and implement long-term goals, set the direction and create well-defined plans to address major challenges and issues related to business development and growth. Today, strategic corporate governance is an integral part of every type and size of business, whether large, medium or small, and plays an important role in the success of any business operation (Zsigmond et al., 2021).

In SMEs, strategic managers can be SME owners, unlike large companies. Thus, the SME owner may be the key person responsible for the strategic management process (Fuertes et al., 2020). Strategic management is about a manager's ability to oversee, control, interpret, and manage a dynamic external and internal environment (Barbosa et al., 2020). It, therefore, depends on how the owners/managers 


\section{INTERNATIONAL JOURNAL OF ENTREPRENEURIAL KNOWLEDGE}

Issue 9, volume 2, ISSN 2336-2960 (Online)

www.ijek.org

implement strategic management, and it depends on the perception, approach and understanding of managers, as different managers may have different approaches to it.

\section{H1: Generation of the respondent has an effect on the perception of attitudes on the management of enterprise.}

The success of SMEs is linked to local economic conditions, as market growth in the SME sector usually occurs at the same pace as the macroeconomy as a whole; therefore, in the event of an economic downturn, SMEs have difficulties (Betáková et al., 2021).

Business market risks are determined by a number of causes, which focus on the overall level of market competitiveness (Malega et al., 2019). Market risk can be defined as the strategic risk of SMEs, which consists in the long-term retention of existing customers and in finding and retaining new customers and producing new products or providing new services (Beck \& Demirguc-Kunt, 2006). Only a sufficient number of customers allows SMEs to achieve a reasonable sales volume that will allow them to remain in the market (Herath \& Mahmood, 2014).

The level of a company's competitiveness is decisively influenced by two main factors of the competitive environment: customers and competitors (De Clercq et al., 2013).

\section{H2: Generation of the respondent has an effect on the perception of attitudes on market risk sources.}

The financial risks of a business are considered to be an integral part of the company's activities. The assessment of a company's financial performance is made on the basis of successful financial risk management decisions (Mättö \& Niskanen, 2021; Sánchez-Ballesta \& Yagüe, 2021). Yang (2017) also argues that mismanagement of company's financial aspects is one of the main threats to the business of SMEs. Difficulties in financing a business and a lack of financial resources are the most common manifestations of the financial risk of SMEs, as most of the capital for the operation of SMEs is financed by the owners themselves (Bosma et al., 2018). The consequences can be reflected in rising operating costs, growing corporate debt, and the problem of debt repayment (Prijadi et al., 2020). Aparicio et al. (2016) argue that the availability of finance in the SME segment improves the quality of the business environment because it motivates SMEs to be more productive. In this context, Wang (2016) states that SME owners consider access to finance, the value of tax rates and competition to be the main barriers to external financing.

Fernandez-Gamez et al. (2020) emphasize that SMEs cannot be assessed (or are insufficiently assessed) solely on the basis of their economic and financial indicators. In the context of globalized markets and internationalized companies, other indicators relating to the country in which the company operates must also be taken into account. The author also supports the profiling of companies based on their financial variables and the specific macroeconomic and regulatory factors of each country.

\section{H3: Generation of the respondent has an effect on the perception of attitudes on financial risk sources.}

The quality of human capital in a company is the basis for increasing the company's performance (Gede Riana et al., 2020). Human capital is a potential for a company, but it can carry risks that are often very neglected (Becker \& Smidt, 2016). El Shoubaki et al. (2020) argue, based on a study of 46,412 SMEs in France, that human capital (using a new idea, the desire to be independent) is the motivation to start a business.

Mura et al. (2017) argue that the voluntary efforts of employees increase productivity and ultimately its performance. This creates a competitive advantage for the business. It is important to develop positive interpersonal relationships between individuals working at different levels in the organization (Alnoor, 


\section{INTERNATIONAL JOURNAL OF ENTREPRENEURIAL KNOWLEDGE}

Issue 9, volume 2, ISSN 2336-2960 (Online)

www.ijek.org

2020). When employees cooperated with others to create social-interpersonal relationships, this confirmed the needs of employee association (Afsar \& Badir, 2016) and belonging (Adamopoulou et al., 2016). Theories of social exchange and reciprocity explain how managers and co-workers' behavior determine the quality of these relationships (Deckop et al., 2003) and influence employee judgment (Redmond \& Sharafizad, 2020).

Gede Riana et al. (2020) conducted a questionnaire data collection that was applied to measure HRM using the Likert scale. An analysis of 126 SME managers showed that HRM significantly affects the company's performance and innovation. The authors also found that innovation can improve an organization's performance. In this context, Konstantopoulou et al. (2019) argue that the lack of attention paid to investment in human resources has become one of the obstacles for SMEs to innovate. AlHaddad et al. (2019) have shown that SMEs play a crucial role in job creation. The authors also argue that there is a positive relationship between SMEs and reducing unemployment. And also between SMEs and raising income levels.

\section{H4: Generation of the respondent has an effect on the perception of attitudes on personal risk sources.}

The legal risks of doing business are a factor that SMEs cannot ignore when doing business in the postmodern age. If legal risks are properly managed in SMEs, then SMEs will easily achieve good financial results and avoid additional costs, such as fines and punitive damages, which will ultimately reduce profitability and also endanger the business (Deligonul, 2020). Reverte (2015) argues that SMEs can achieve sustainability and stability in business if they accept the presence of legal aspects.

Pereira et al. (2015) stated that there are relationships and legal links between the legal aspects of SMEs in the V4 countries and in Ukraine. SMEs in the V4 countries and Ukraine are inherently exposed to the legal risks of doing business, as SMEs are considered a key element of the business environment. For this reason, a direct business effect can be seen when legal risk management failure is assumed (Gwizdała, 2017). Managing the legal risks of SMEs in the Czech Republic and the V4 countries facilitates the process of using loans and other credit resources from financial institutions and European communities, thus creating a healthy business environment (Virglerova et al., 2020).

In research conducted by Grau \& Reig (2020), the authors found that although SMEs are undergoing changes due to changes in legislation, they still have the ability to adapt better than large companies. When examining legislative changes, SMEs are able to ensure that the changes do not undermine their sustainability in terms of profitability, operation and investment.

\section{H5: Generation of the respondent has an effect on the perception of attitudes on legal risk sources.}

The impact of the corporate capacity of SMEs on the competitive advantage was assessed by Games \& Roliza (2019), taking into account the age of the company. In the case of Indonesia, the inward capacity of SMEs was strongly and positively correlated with competitive advantage. In the case of SMEs with less than five years of activity in the business environment, this dependence is weaker compared to older companies. Bayaga \& Flowerday (2010) point out that inadequately developed internal processes or the failure of the company's internal processes are directly related to the performance of SMEs.

Innovation has a profound and significant impact on firms' competitiveness through increased productivity, as shown by a study for transition markets (Ngoc Mai et al., 2019). Santa et al. (2019) analyzed the internal and external determinants of companies' innovation capacity based on World Economic Forum data sets of 135 countries over 10 years on a total sample of 1,239 observations. The central determinant based on the application of a holistic approach is direct public and private financial support for research and development. 


\section{INTERNATIONAL JOURNAL OF ENTREPRENEURIAL KNOWLEDGE}

Issue 9, volume 2, ISSN 2336-2960 (Online)

www.ijek.org

Doran et al. (2019) in their study of the business environment for SMEs in Ireland, point out that SMEs generate innovation internally through $\mathrm{R} \& \mathrm{D}$ while also using external resources. However, the impact of external sources is not uniform. The results suggest that feedback has a positive effect on SME product innovation, but negatively affects SME process innovation. Public sources of knowledge are positively related to product innovation. Another finding is that SMEs consider process innovation to be a key factor in SME productivity. Product innovation does not affect the performance of SMEs.

Brunswicker \& Vanhaverbeke (2015) in a sample of 1411 SMEs found that SMEs use four types of external knowledge acquisition - minimal supply chain, technology-oriented, application-oriented and complex sourcing.

H6: Generation of the respondent has an effect on the perception of attitudes on operational risk sources.

\section{DATA, METHODOLOGY AND METHODS}

The aim of article is identify common features and disparities in the perception of business risks between generation $\mathrm{X}, \mathrm{Y}$ and $\mathrm{Z}$ of entrepreneurs in the small and medium-sized enterprises (SMEs). The criterion of research is type of generation of respondent (Gen. $\mathrm{X}$ - age of respondent older than 45 years ( $\mathrm{n}=$ $798 ; 50.3 \%)$; Gen. Y - age of respondent 35 and 45 years ( $\mathrm{n}=475 ; 30.0 \%)$; Gen. $\mathrm{Z}$ - age of respondent younger than 35 year $(n=312 ; 19.7 \%))$.

Data collection was realised by means of questionnaire (combined online and hard version). The respondent was defined as a business owner or senior manager of a small and medium-sized enterprise in V4 countries. The time period of data collection was realized during 9/2019 - 4/2020. Random selection of SMEs was used for each country from the CRIBIS database for Czech Republic (CR) and Slovak Republic (SR), the database of chambers of commerce and industry in Budapest for Hungary, the database of the Central Statistical Office for Poland. The process of data collection contained these steps (separately for each country - SR, CR, PL, H): i. define of the range SMEs (criterion: SMEs up to 249 employees); ii. assignment of a serial number according to the database; iii. random numbers generated using the mathematical function "Randbetween"; iv. assignment of SMEs to randomly generated numbers; v. finding contacts and addressing SMEs by e-mail with a request.

SMEs (more than 30,000) were contacted with a request to complete the questionnaire. The response rate was more than $5.0 \%$. The questionnaires were translated from English into the national languages of the respondents. The consistency of the respondents' answers was verified by a control question. The questionnaire was formulated in such a way as to prevent the computer from filling in the questionnaire automatically. The business risk sources (see tab. 1) were use on the evaluation of the article's hypotheses. The respondent had to answer one of the following answers: A1 - completely agree, A2 - agree, A3 - I do not take a position, A4 - disagree, A5 - completely disagree.

Table 1 Business risk sources

\begin{tabular}{|c|c|}
\hline TR & Risk source (RS) \\
\hline \multirow{3}{*}{ MN } & RS1: I do business (manage a company) intensively (more than 8 hours a day). \\
\hline & $\begin{array}{l}\text { RS2: I apply a participative management style (involving employees in decision } \\
\text { making). }\end{array}$ \\
\hline & $\begin{array}{l}\text { RS3: The business owner (manager) should regularly evaluate the performance of their } \\
\text { subordinates and motivate them to innovate workflows. }\end{array}$ \\
\hline
\end{tabular}


INTERNATIONAL JOURNAL OF ENTREPRENEURIAL KNOWLEDGE

Issue 9, volume 2, ISSN 2336-2960 (Online)

www.ijek.org

\begin{tabular}{|c|c|}
\hline \multirow{3}{*}{ MR } & RS4: Businesscompetition motivates me to perform better. \\
\hline & $\begin{array}{l}\text { RS5: Selling products and services on the market is challenging. However, our } \\
\text { company has adequate sales volume. }\end{array}$ \\
\hline & $\begin{array}{l}\text { RS 6: Our company uses innovative ways to win new markets and retain existing } \\
\text { customers. }\end{array}$ \\
\hline \multirow{3}{*}{ FR } & RS7: I consider financial risk as part of everyday business. \\
\hline & RS8: I understand the most crucial aspect of financial risk. \\
\hline & RS9: I can adequately manage the financial risk in my (our) company. \\
\hline \multirow{3}{*}{ PR } & $\begin{array}{l}\text { RS10: Personnel risk in the company is considered adequate and does not harm my } \\
\text { business. }\end{array}$ \\
\hline & $\begin{array}{l}\text { RS11: The error rate of employees is low and has no negative impact on my (our) } \\
\text { business. }\end{array}$ \\
\hline & $\begin{array}{l}\text { RS12: Our employees strive to improve their performance and competition among } \\
\text { them prevails. }\end{array}$ \\
\hline \multirow{3}{*}{ LR } & RS13: I consider the legal risk-appropriate and does not harm our (my) business. \\
\hline & RS14: I do not consider the business environment to be 'over-regulated'. \\
\hline & RS15: I understand the essential legal aspects of doing business. \\
\hline \multirow{3}{*}{ OR } & RS16: We use company capacities at a sufficient level. \\
\hline & $\begin{array}{l}\text { RS17: We place great emphasis on the innovation of our products and services, and it } \\
\text { is positively reflected in the stability and performance of the company. }\end{array}$ \\
\hline & $\begin{array}{l}\text { RS18: The number of possible requests for specific products/services has a downward } \\
\text { trend. }\end{array}$ \\
\hline
\end{tabular}

Note: TR - Type of risk; MN - management of enterprise; MR - Market risk; FR - Financial risk; PR - Personnel risk; LR Legal risk, OR - Operational risk.

\section{(Source: Own data collection)}

The results of a sample size analysis are as follows. The minimum number of SMEs was calculated with the following data: margin of error - 5\%; confidence level - 99\%; number of SMEs in the V4 countries (together) - 4.5 mil. The results showed that the minimum of SMEs $(n=666)$ was confirmed for the research sample. The research sample contains 1585 correctly fulfill questionnaires.

The process of verification of hypotheses contains the four steps: 1 . Creation of contingency tables absolute and relative frequencies according to the respondent's age; the type of answer on the risk source. 2. Evaluation of significant disparities between generations - applied the Chi-square tests (Ch. S.) and the non-parametric approach (Kruskal-Wallis tests) 3. Evaluation of significant disparities in the positive attitudes (A1+A2) between generations - applied the Z-Score for 2 population proportions. 4. Definition of level of significance $(\alpha)$ - in tables: $\alpha=5 \% ; \alpha=1 \% ; \alpha=0.1 \%$; in conclusions: $\alpha=5 \%$.

Demographic structure of respondents according to the characteristics of SMEs/respondents ( $\mathrm{n}=1585)$ : country of SMEs: $28.6 \%$ from (CR, 23.2\% from SR, 23.0\% from PL, 25.2\% from H; size of an enterprise: $61.6 \%$ micro enterprise, $18.8 \%$ small enterprise, $19.6 \%$ medium enterprise; type of an entity: $30.2 \%$ sole trader, $56.7 \%$ limited liability company, $6.0 \%$ joint-stock company, $7.1 \%$ another form of business; time period of doing business: $9.2 \%(0 ; 3$ years $>, 8.8 \%(3 ; 5$ years $>, 15.8 \%(5 ; 10$ years $>, 66.2 \%$ more than 10 years; the highest level of respondent's education: $28.2 \%$ comprehensive college and high school graduate, $14.3 \%$ bachelor's degree, $50.0 \%$ master's degree, $7.5 \%$ doctoral degree; gender of a respondent: $68.2 \%$ men, $31.8 \%$ women; position of a respondent in the SME: $26.6 \%$ business owner; $73.4 \%$ senior manager. 
INTERNATIONAL JOURNAL OF ENTREPRENEURIAL KNOWLEDGE

Issue 9, volume 2, ISSN 2336-2960 (Online)

www.ijek.org

\section{EMPIRICAL RESULTS}

Table 2 presented the evaluation of validity and reliability of questionnaire according to the following indicators: FL - Factor loading; CA - Cronbach alpha; CR - Composite reliability; AVE - Average variance extracted.

Table 2 The results of validity and reliability of questionnaire

\begin{tabular}{|c|c|c|c|c|c|c|c|c|c|c|c|}
\hline TR & RS & FL & CA & CR & AVE & TR & RS & FL & CA & CR & AVE \\
\hline \multirow{3}{*}{$\mathbf{M N}$} & RS1 & 0.674 & \multirow{3}{*}{0.706} & \multirow{3}{*}{0.769} & \multirow{3}{*}{0.527} & \multirow{3}{*}{ PR } & RS10 & 0.739 & \multirow{3}{*}{0.757} & \multirow{3}{*}{0.814} & \multirow{3}{*}{0.593} \\
\hline & RS2 & 0.733 & & & & & RS11 & 0.804 & & & \\
\hline & RS3 & 0.768 & & & & & RS12 & 0.766 & & & \\
\hline \multirow{3}{*}{ MR } & RS4 & 0.749 & \multirow{3}{*}{0.732} & \multirow{3}{*}{0.804} & \multirow{3}{*}{0.578} & \multirow{3}{*}{ LR } & RS13 & 0.801 & \multirow{3}{*}{0.716} & \multirow{3}{*}{0.795} & \multirow{3}{*}{0.565} \\
\hline & RS5 & 0.780 & & & & & RS14 & 0.763 & & & \\
\hline & RS6 & 0.751 & & & & & RS15 & 0.687 & & & \\
\hline \multirow{3}{*}{ FR } & RS7 & 0.656 & \multirow{3}{*}{0.784} & \multirow{3}{*}{0.838} & \multirow{3}{*}{0.637} & \multirow{3}{*}{ OR } & RS16 & 0.796 & \multirow{3}{*}{0.721} & \multirow{3}{*}{0.751} & \multirow{3}{*}{0.510} \\
\hline & RS8 & 0.879 & & & & & RS17 & 0.794 & & & \\
\hline & RS9 & 0.841 & & & & & RS18 & 0.516 & & & \\
\hline
\end{tabular}

(Source: Own data collection)

The results showed (see table 2) that CAs and CRs of each are greater than 0.70 (the minimum criterion). The results further exhibited (see table 2) that FLs of all RS are in the interval of 0.591 to 0.852 , meeting the discriminant validity. The value of AVE is more significant than 0.50 for each RS, which meets the constructs' convergent validity criterion.

\subsection{Evaluation of management of enterprise}

The structure of the respondents' attitudes ( $\mathrm{n}=1585$; management risk sources- RS1, RS2, RS3) were: RS1: A1+A2 - 1101 (69.5\%), A3 - 239 (15.1\%), A4+A5 - 265 (15.5\%); RS2: A1+A2 - 1055 (66.6\%), A3 - 276 (17.4\%), A4+A5 - 254 (16.1\%); RS3: A1+A2 - 1347 (85.0\%), A3 - 159 (10.0\%), A4+A5 - 79 $(5.0 \%)$. Table 3 showed the evaluation of management risk sources according to the age of respondent.

Table 3 The attitudes of respondents on the management risk sources

\begin{tabular}{|c|c|c|c|c|c|c|c|c|c|c|c|}
\hline \multirow[b]{2}{*}{ T. A. } & \multicolumn{4}{|c|}{ RS1 } & \multicolumn{4}{|c|}{ RS2 } & \multicolumn{3}{|c|}{ RS3 } \\
\hline & Gen. Z & \multicolumn{2}{|c|}{ Gen. Y } & Gen. $\mathbf{X}$ & Gen. $\mathrm{Z}$ & & n. $Y$ & Gen. X & $\begin{array}{c}\text { Gen. } \\
Z\end{array}$ & $\begin{array}{c}\text { Gen. } \\
\text { Y }\end{array}$ & Gen. $\mathbf{X}$ \\
\hline A1 & 129 & \multicolumn{2}{|c|}{205} & 368 & 95 & \multicolumn{2}{|c|}{124} & 221 & 178 & 230 & 376 \\
\hline A2 & 76 & \multicolumn{2}{|c|}{124} & 199 & 100 & \multicolumn{2}{|c|}{179} & 336 & 87 & 163 & 313 \\
\hline $\begin{array}{c}\mathrm{A} 1+\mathrm{A} 2 \\
\%\end{array}$ & $\begin{array}{c}205 \\
(65.7)\end{array}$ & \multicolumn{2}{|c|}{$\begin{array}{c}329 \\
(69.3)\end{array}$} & $\begin{array}{c}567 \\
(71.1)\end{array}$ & $\begin{array}{c}195 \\
(62.5)\end{array}$ & \multicolumn{2}{|c|}{$\begin{array}{c}303 \\
(63.8)\end{array}$} & $\begin{array}{c}557 \\
(69.8)\end{array}$ & $\begin{array}{c}265 \\
(84.9 \\
)\end{array}$ & $\begin{array}{c}393 \\
(82.7)\end{array}$ & $\begin{array}{c}689 \\
(86.3)\end{array}$ \\
\hline A3 & 52 & \multicolumn{2}{|c|}{54} & 133 & 65 & & 90 & 121 & 26 & 52 & 81 \\
\hline A4 & 34 & 5 & & 60 & 25 & & 51 & 77 & 11 & 14 & 13 \\
\hline A5 & 21 & 3 & & 38 & 27 & & 31 & 43 & 10 & $\frac{16}{671^{* *}}$ & 15 \\
\hline Ch. S. & \multicolumn{4}{|c|}{$19.076^{*}(0.014)$} & \multicolumn{4}{|c|}{$17.628^{*}(0.024)$} & \multicolumn{3}{|c|}{$21.671^{* *}(0.006)$} \\
\hline $\begin{array}{c}\text { Z- } \\
\text { Score }\end{array}$ & \multicolumn{2}{|c|}{$\begin{array}{c}\text { Gen.X/Gen } \\
\text {.Y }\end{array}$} & \multicolumn{2}{|c|}{$\begin{array}{c}\text { Gen.Y/Gen } \\
. Z\end{array}$} & \multicolumn{2}{|c|}{$\begin{array}{c}\text { Gen.X/Gen } \\
\text {.Y } \\
\end{array}$} & \multicolumn{2}{|c|}{$\begin{array}{c}\text { Gen.Y/Gen } \\
. Z\end{array}$} & \multicolumn{2}{|c|}{$\begin{array}{c}\text { Gen.X/Gen } \\
\text {.Y }\end{array}$} & \begin{tabular}{|c|} 
Gen.Y/Gen \\
.$Z$ \\
\end{tabular} \\
\hline
\end{tabular}


INTERNATIONAL JOURNAL OF ENTREPRENEURIAL KNOWLEDGE

Issue 9, volume 2, ISSN 2336-2960 (Online)

www.ijek.org

\begin{tabular}{|c|c|c|c|c|c|c|}
\hline \multirow[t]{3}{*}{$\begin{array}{l}\text { A1+A2 } \\
\text { (p-val.) }\end{array}$} & $0.676(0.497)$ & $1.045(0.294)$ & $\begin{array}{l}2.215^{*} \\
(0.026)\end{array}$ & $0.367(0.711)$ & $1.742(0.082)$ & $\stackrel{-}{-} 0.815(0.412)$ \\
\hline & \multicolumn{2}{|c|}{ Gen. X / Gen. Z } & \multicolumn{2}{|c|}{ Gen. X / Gen. Z } & \multicolumn{2}{|c|}{ Gen. X / Gen. Z } \\
\hline & \multicolumn{2}{|c|}{$1.740(0.082)$} & \multicolumn{2}{|c|}{$2.339^{*}(0.019)$} & \multicolumn{2}{|c|}{$0.605(0.542)$} \\
\hline
\end{tabular}

Note: T.A. - Type of answer; ${ }^{*} \alpha=5 \% ;{ }^{* *} \alpha=1 \%$; Ch.S. - Chi-square test.

(Source: Own data collection)

The results (see tab. 3) confirm that there are statistically significant differences between generations (X, $\mathrm{Y}, \mathrm{Z}$ ) in the perception of the MN sources (RS1: p-value $=0.014$; RS2: $\mathrm{p}$-value $=0.024$; RS3: $\mathrm{p}$-value $=$ 0.006). Also, there are statistically significant differences in positive answers between generations: $\mathrm{X}-\mathrm{Y}$ $(\mathrm{RS} 2: \mathrm{p}$-value $=0.026)$ and X-Z $(\mathrm{RS} 2: \mathrm{p}$ - value $=0.019)$. Hypothesis H1 was confirmed .

\subsection{Evaluation of market risk sources}

The Structure of the respondents' attitudes ( $\mathrm{n}=1585$; market risk sources $-\mathrm{RS} 4$, RS5, RS6) were: RS4: A1+A2 - 1131 (71.4\%), A3 - 277 (17.5\%), A4+A5 - 177 (11.1\%); RS5: A1+A2 - 1022 (64.5\%), A3 375 (23.7\%), A4+A5 - 188 (11.8\%); RS6: A1+A2 - 796 (50.2\%), A3 - 457 (28.8\%), A4+A5 - 332 $(21.0 \%)$. Table 4 showed the evaluation of market risk sources according to the age of respondent.

Table 4 The attitudes of respondents on the market risk sources

\begin{tabular}{|c|c|c|c|c|c|c|c|c|c|c|c|c|}
\hline \multirow{2}{*}{ T. A. } & \multicolumn{4}{|c|}{ RS4 } & \multicolumn{4}{|c|}{ RS5 } & \multicolumn{4}{|c|}{ RS6 } \\
\hline & Gen. Z & \multicolumn{2}{|c|}{ Gen. Y } & Gen. X & Gen. Z & \multicolumn{2}{|c|}{ Gen. Y } & Gen. X & Gen. $Z$ & \multicolumn{2}{|c|}{ Gen. Y } & Gen. X \\
\hline A1 & 127 & \multicolumn{2}{|c|}{132} & 217 & 66 & \multicolumn{2}{|c|}{59} & 142 & 72 & \multicolumn{2}{|c|}{60} & 101 \\
\hline A2 & 109 & \multicolumn{2}{|c|}{202} & 344 & 137 & \multicolumn{2}{|c|}{242} & 376 & 101 & \multicolumn{2}{|c|}{183} & 279 \\
\hline $\begin{array}{c}\mathrm{A} 1+\mathrm{A} 2 \\
\%\end{array}$ & $\begin{array}{c}236 \\
(75.6)\end{array}$ & \multicolumn{2}{|c|}{$\begin{array}{c}334 \\
(70.3) \\
\end{array}$} & $\begin{array}{c}561 \\
(70.3)\end{array}$ & $\begin{array}{c}203 \\
(65.1)\end{array}$ & \multicolumn{2}{|c|}{$\begin{array}{c}301 \\
(63.4) \\
\end{array}$} & $\begin{array}{c}518 \\
(64.9)\end{array}$ & $\begin{array}{c}173 \\
(55.4)\end{array}$ & \multicolumn{2}{|c|}{$\begin{array}{c}243 \\
(51.2) \\
\end{array}$} & $\begin{array}{c}380 \\
(47.6)\end{array}$ \\
\hline A3 & 35 & \multicolumn{2}{|c|}{80} & 162 & 68 & \multicolumn{2}{|c|}{111} & 196 & 81 & \multicolumn{2}{|c|}{128} & 248 \\
\hline A4 & 28 & \multicolumn{2}{|c|}{39} & 59 & 34 & \multicolumn{2}{|c|}{53} & 65 & 45 & \multicolumn{2}{|c|}{82} & 134 \\
\hline A5 & 13 & \multicolumn{2}{|c|}{22} & 16 & 7 & \multicolumn{2}{|c|}{10} & 19 & 13 & \multicolumn{2}{|c|}{22} & 36 \\
\hline Ch. S. & \multicolumn{4}{|c|}{$37.613^{* * *}(0.000)$} & \multicolumn{4}{|c|}{$15.793^{*}(0.045)$} & \multicolumn{4}{|c|}{$24.684^{* *}(0.002)$} \\
\hline \multirow{4}{*}{$\begin{array}{c}\text { Z- } \\
\text { Score } \\
\text { A1+A2 } \\
\text { (p-val.) }\end{array}$} & \multicolumn{2}{|c|}{$\begin{array}{c}\text { Gen.X/Gen } \\
. Y\end{array}$} & \multicolumn{2}{|c|}{$\begin{array}{c}\text { Gen.Y/Gen } \\
. Z \\
\end{array}$} & \multicolumn{2}{|c|}{$\begin{array}{c}\text { Gen.X/Gen } \\
\text {.Y }\end{array}$} & \multicolumn{2}{|c|}{$\begin{array}{c}\text { Gen.Y/Gen } \\
. Z \\
\end{array}$} & \multicolumn{2}{|c|}{$\begin{array}{c}\text { Gen.X/Gen } \\
. Y\end{array}$} & \multicolumn{2}{|c|}{$\begin{array}{c}\text { Gen.Y/Gen } \\
. Z\end{array}$} \\
\hline & \multicolumn{2}{|c|}{$0.006(0.992)$} & -1. & $35(0.101)$ & $-0.556(0$ & 775) & -0.4 & $85(0.631)$ & $-1.222(0$. & $22)$ & -1.1 & $30(0.238)$ \\
\hline & $\mathrm{Ge}$ & $\mathrm{X}$ & $\mathrm{Ge}$ & & & $\mathrm{X}$ & $\mathrm{G}$ & & & & $C$ & \\
\hline & & 778 & 0.07 & & & .048 & 0.96 & & & $345^{*}$ & 10.0 & \\
\hline
\end{tabular}

Note: T.A. - Type of answer; ${ }^{*} \alpha=5 \%{ }^{* *} \alpha=1 \% ;{ }^{* * *} \alpha=0.1 \%$; Ch.S. - Chi-square test.

(Source: Own data collection)

The results (see tab. 4) confirm that there are statistically significant differences between generations (X, $\mathrm{Y}, \mathrm{Z}$ ) in the perception of the market risk sources (RS4: $\mathrm{p}$-value $=0.000$; RS5: $\mathrm{p}$-value $=0.045$; RS6: $\mathrm{p}$ value $=0.002)$. Also, there are statistically significant differences in positive answers between generations $\mathrm{X}$ and $\mathrm{Z}$ (RS6: $\mathrm{p}$ - value $=0.019)$. Hypothesis $\mathrm{H} 2$ was confirmed.

\subsection{Evaluation of financial risk sources}

The Structure of the respondents' attitudes ( $\mathrm{n}=1585$; financial risk sources- RS7, .., RS9) were: RS7: A1+A2 - 1184 (74.7\%), A3 - 272 (17.2\%), A4+A5 - 129 (8.1\%); RS8: A1+A2 - 1208 (76.2\%), A3 - 289 
INTERNATIONAL JOURNAL OF ENTREPRENEURIAL KNOWLEDGE

Issue 9, volume 2, ISSN 2336-2960 (Online)

www.ijek.org

(18.2\%), A4+A5 - 88 (5.6\%); RS9: A1+A2 - 1125 (71.0\%), A3 - 341 (21.5\%), A4+A5 - 119 (7.5\%). Table 5 showed the evaluation of financial risk sources according to the age of respondent.

Table 5 The attitudes of respondents on the financial risk sources

\begin{tabular}{|c|c|c|c|c|c|c|c|c|c|c|c|c|}
\hline \multirow[b]{2}{*}{ T. A. } & \multicolumn{4}{|c|}{ RS7 } & \multicolumn{4}{|c|}{ RS8 } & \multicolumn{4}{|c|}{ RS9 } \\
\hline & Gen. Z & \multicolumn{2}{|c|}{ Gen. Y } & $\begin{array}{l}\text { Gen. } \\
\text { X }\end{array}$ & Gen. Z & \multicolumn{2}{|c|}{ Gen. Y } & Gen. $X$ & $\begin{array}{c}\text { Gen. } \\
\mathrm{Z}\end{array}$ & \multicolumn{2}{|c|}{ Gen. Y } & Gen. $\mathbf{X}$ \\
\hline A1 & 93 & \multicolumn{2}{|c|}{108} & 241 & 91 & \multicolumn{2}{|c|}{115} & 215 & 73 & \multicolumn{2}{|c|}{82} & 176 \\
\hline A2 & 130 & \multicolumn{2}{|c|}{227} & 385 & 140 & \multicolumn{2}{|c|}{259} & 388 & 140 & \multicolumn{2}{|c|}{265} & 389 \\
\hline $\begin{array}{c}\mathrm{A} 1+2 \\
\%\end{array}$ & $\begin{array}{c}223 \\
(71.5)\end{array}$ & \multicolumn{2}{|c|}{$\begin{array}{c}335 \\
(70.5)\end{array}$} & $\begin{array}{c}626 \\
(78.5)\end{array}$ & $\begin{array}{c}231 \\
(74.0)\end{array}$ & \multicolumn{2}{|c|}{$\begin{array}{c}374 \\
(78.7)\end{array}$} & $\begin{array}{c}603 \\
(75.6)\end{array}$ & $\begin{array}{c}213 \\
(68.3)\end{array}$ & \multicolumn{2}{|c|}{$\begin{array}{c}347 \\
(73.1)\end{array}$} & $\begin{array}{c}565 \\
(70.8)\end{array}$ \\
\hline A3 & 57 & \multicolumn{2}{|c|}{103} & 112 & 58 & \multicolumn{2}{|c|}{69} & 162 & 73 & \multicolumn{2}{|c|}{82} & 186 \\
\hline A4 & 25 & \multicolumn{2}{|c|}{30} & 47 & 16 & \multicolumn{2}{|c|}{24} & 23 & 21 & \multicolumn{2}{|c|}{37} & 36 \\
\hline A5 & 7 & & 7 & 13 & 7 & \multicolumn{2}{|c|}{8} & 10 & 5 & \multicolumn{2}{|c|}{9} & 11 \\
\hline $\begin{array}{l}\text { Ch. } \\
\text { S. }\end{array}$ & \multicolumn{4}{|c|}{$21.398^{* *}(0.006)$} & \multicolumn{4}{|c|}{$17.454^{*}(0.026)$} & \multicolumn{4}{|c|}{$21.531^{* *}(0.006)$} \\
\hline \multirow{4}{*}{$\begin{array}{c}\mathrm{Z}- \\
\text { Score } \\
\mathrm{A} 1+\mathrm{A} \\
2 \\
\text { (p- } \\
\text { val.) }\end{array}$} & \multicolumn{2}{|c|}{$\begin{array}{c}\text { Gen.X/Gen } \\
\text {.Y }\end{array}$} & \multicolumn{2}{|c|}{$\begin{array}{c}\text { Gen.Y/Gen } \\
. Z \\
\end{array}$} & \multicolumn{2}{|c|}{$\begin{array}{c}\text { Gen.X/Gen } \\
\text {.Y }\end{array}$} & \multicolumn{2}{|c|}{$\begin{array}{c}\text { Gen.Y/Gen } \\
. Z\end{array}$} & \multicolumn{2}{|c|}{$\begin{array}{c}\text { Gen.X/Gen. } \\
\text { Y }\end{array}$} & \multicolumn{2}{|c|}{$\begin{array}{c}\text { Gen.Y/Gen } \\
. Z \\
\end{array}$} \\
\hline & \multicolumn{2}{|c|}{$3.177^{* *}(0.001$} & \multicolumn{2}{|c|}{$-0.286(0.772)$} & $-1.296(0$ & 94) & 1.5 & $9(0.126)$ & $-0.862(0$. & & 1.44 & $9(0.147)$ \\
\hline & Ger & $\mathbf{X}$ & $\mathrm{Ge}$ & & & . $\mathrm{X}$ & $\mathrm{Ge}$ & & & $\mathrm{X}$ & $\mathrm{Ger}$ & \\
\hline & & $162^{*}$ & 0.01 & & & .529 & 0.59 & & & .828 & $0.40^{7}$ & \\
\hline
\end{tabular}

Note: T.A. - Type of answer; ${ }^{*} \alpha=5 \% ;{ }^{* *} \alpha=1 \%$; Chi. S. - Chi-square test.

(Source: Own data collection)

The results (see tab. 5) confirm that there are statistically significant differences between generations (X, $\mathrm{Y}, \mathrm{Z}$ ) in the perception of the financial risk sources (RS7: $\mathrm{p}$-value $=0.006$; RS8: $\mathrm{p}$-value $=0.026$; RS9: $\mathrm{p}$ value $=0.006)$. Also, there are statistically significant differences in positive answers between generations: $\mathrm{X}-\mathrm{Y}(\mathrm{RS} 7: \mathrm{p}$-value $=0.001)$ and X-Z $(\mathrm{RS} 7: \mathrm{p}$ - value $=0.014)$. Hypothesis H3 was confirmed.

\subsection{Evaluation of personnel risk sources}

The Structure of the respondents' attitudes ( $\mathrm{n}=1585$; personnel risk sources $-\mathrm{RS10}$, RS11, RS12) were: RS10: A1+A2 - 826 (52.1\%), A3 - 432 (27.3\%), A4+A5 - 327 (20.6\%); RS11: A1+A2 - 914 (57.7\%), A 3 - 356 (22.5\%), A4+A 5 - 315 (19.8\%); RS12: A1+A2 - 729 (46.0\%), A3 - 521 (32.9\%), A4+A 5 - 335 $(21.1 \%)$. Table 6 showed the evaluation of personnel risk sources according to the age of respondent.

Table 6. The attitudes of respondents on the personnel risk sources

\begin{tabular}{|c|c|c|c|c|c|c|c|c|c|}
\hline & \multicolumn{3}{|c|}{ RS10 } & \multicolumn{3}{c|}{ RS11 } & \multicolumn{3}{c|}{ RS12 } \\
\cline { 2 - 10 } T. A. & Gen. Z & Gen. Y & $\begin{array}{c}\text { Gen. } \\
\text { X }\end{array}$ & Gen. Z & Gen. Y & Gen. X & $\begin{array}{c}\text { Ge } \\
\text { n. } \\
\text { Z }\end{array}$ & Gen. Y & Gen. X \\
\hline A1 & 64 & 49 & 101 & 83 & 68 & 159 & 64 & 51 & 99 \\
\hline A2 & 118 & 188 & 306 & 106 & 176 & 322 & 84 & 158 & 273 \\
\hline A1+A & 182 & 237 & 407 & 189 & 244 & 481 & 148 & 209 & 372 \\
$\mathbf{2}$ & $(58.3)$ & $(49.9)$ & $(51.0)$ & $(60.6)$ & $(51.4)$ & $(60.3)$ & & $(44.0)$ & $(46.6)$ \\
\hline
\end{tabular}


INTERNATIONAL JOURNAL OF ENTREPRENEURIAL KNOWLEDGE

Issue 9, volume 2, ISSN 2336-2960 (Online)

www.ijek.org

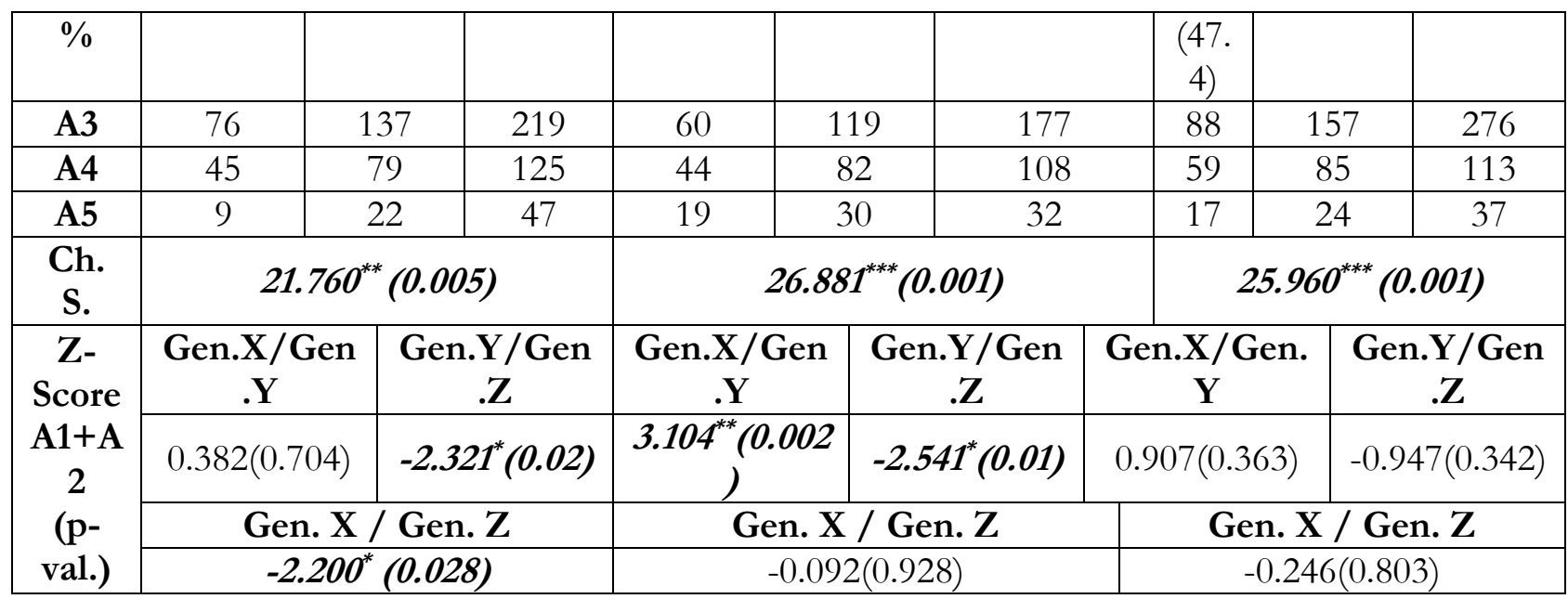

Note: T.A. - Type of answer, ${ }^{* *} \alpha=1 \% ;{ }^{* * *} \alpha=0.1 \%$; Ch.S. - Chi-square test.

(Source: Own data collection)

The results (see tab. 6) confirm that there are statistically significant differences between generations (X, $\mathrm{Y}, \mathrm{Z}$ ) in the perception of the personnel risk sources (RS10: $\mathrm{p}$-value $=0.005$; RS11: $\mathrm{p}$-value $=0.001$; RS12: $\mathrm{p}$-value $=0.001)$. Also, there are statistically significant differences in positive answers between generations: $\mathrm{X}-\mathrm{Y}(\mathrm{RS11}$ : $\mathrm{p}$-value $=0.002) ; \mathrm{X}-\mathrm{Z}(\mathrm{RS10}$ : $\mathrm{p}$ - value $=0.028)$ and $\mathrm{Y}-\mathrm{Z}(\mathrm{RS10}$ : $\mathrm{p}$-value $=0.020$; RS11: $\mathrm{p}$ - value $=0.010)$. Hypothesis H4 was confirmed.

\subsection{Evaluation of legal risk sources}

The Structure of the respondents' attitudes ( $\mathrm{n}=1585$; legal risk sources $-\mathrm{RS13}$, RS14, RS15) were: RS13: A1+A2 - 702 (44.3\%), A3 - 437 (27.6\%), A4+A5 - 446 (28.1\%); RS14: A1+A2 - 467 (29.5\%), A3 - 434 (27.4\%), A4+A5 - 684 (43.1\%); RS15: A1+A2 - 1269 (80.1\%), A3 - 247 (15.6\%), A4+A5 - 69 (4.3\%). Table 7 showed the evaluation of legal risk sources according to the age of respondent.

Table 7. The attitudes of respondents on the legal risk sources

\begin{tabular}{|c|c|c|c|c|c|c|c|c|c|c|c|c|}
\hline \multirow[b]{2}{*}{ T. A. } & \multicolumn{4}{|c|}{ RS13 } & \multicolumn{4}{|c|}{ RS14 } & \multicolumn{4}{|c|}{ RS15 } \\
\hline & Gen. $\mathrm{Z}$ & \multicolumn{2}{|c|}{ Gen. Y } & Gen. $\mathbf{X}$ & Gen. Z & \multicolumn{2}{|c|}{ Gen. Y } & $\begin{array}{l}\text { Gen. } \\
\mathbf{X}\end{array}$ & Gen. Z & \multicolumn{2}{|c|}{ Gen. Y } & Gen. $\mathbf{X}$ \\
\hline A1 & 65 & \multicolumn{2}{|c|}{47} & 71 & 42 & \multicolumn{2}{|c|}{36} & 64 & 114 & \multicolumn{2}{|c|}{150} & 234 \\
\hline A2 & 94 & \multicolumn{2}{|c|}{171} & 254 & 66 & \multicolumn{2}{|c|}{106} & 153 & 130 & \multicolumn{2}{|c|}{219} & 422 \\
\hline $\begin{array}{c}\mathbf{A} 1+\mathbf{A} \\
2 \\
\%\end{array}$ & $\begin{array}{c}159 \\
(51.0)\end{array}$ & \multicolumn{2}{|c|}{$\begin{array}{c}218 \\
(45.9)\end{array}$} & $\begin{array}{c}325 \\
(40.7)\end{array}$ & $\begin{array}{c}108 \\
(34.6)\end{array}$ & \multicolumn{2}{|c|}{$\begin{array}{c}142 \\
(29.9)\end{array}$} & $\begin{array}{c}217 \\
(27.2)\end{array}$ & $\begin{array}{c}244 \\
(78.2)\end{array}$ & \multicolumn{2}{|c|}{$\begin{array}{c}369 \\
(77.7)\end{array}$} & $\begin{array}{c}656 \\
(82.2)\end{array}$ \\
\hline A3 & 73 & \multicolumn{2}{|c|}{125} & 239 & 92 & \multicolumn{2}{|c|}{143} & 199 & 48 & \multicolumn{2}{|c|}{85} & 114 \\
\hline A4 & 56 & \multicolumn{2}{|c|}{94} & 157 & 70 & \multicolumn{2}{|c|}{111} & 228 & 14 & \multicolumn{2}{|c|}{12} & 21 \\
\hline A5 & 24 & \multicolumn{2}{|c|}{38} & 77 & 42 & \multicolumn{2}{|c|}{79} & 154 & 6 & \multicolumn{2}{|c|}{$\begin{array}{c}9 \\
07^{*}(0)\end{array}$} & 7 \\
\hline Ch.S. & \multicolumn{4}{|c|}{$37.398^{* * *}(0.000)$} & \multicolumn{4}{|c|}{$23.341^{* *}(0.003)$} & \multicolumn{4}{|c|}{$18.987^{*}(0.015)$} \\
\hline \multirow{4}{*}{$\begin{array}{c}\mathrm{Z}- \\
\text { Score } \\
\text { A1+A } \\
2 \\
\text { (p- } \\
\text { val.) }\end{array}$} & \multicolumn{2}{|c|}{$\begin{array}{c}\text { Gen.X/Gen } \\
\text {.Y }\end{array}$} & \multicolumn{2}{|c|}{$\begin{array}{c}\text { Gen.Y/Gen } \\
. Z\end{array}$} & \multicolumn{2}{|c|}{$\begin{array}{c}\text { Gen.X/Gen } \\
\text {.Y }\end{array}$} & \multicolumn{2}{|c|}{$\begin{array}{c}\text { Gen.Y/Gen } \\
. Z\end{array}$} & \multicolumn{2}{|c|}{$\begin{array}{c}\text { Gen.X/Gen } \\
\text {.Y }\end{array}$} & \multicolumn{2}{|c|}{$\begin{array}{c}\text { Gen.Y/Gen } \\
. Z\end{array}$} \\
\hline & \multicolumn{2}{|c|}{$-1.803(0.072)$} & -1.3 & $2(0.165)$ & $-1.036(0$. & & -1.3 & $1(0.165)$ & $1.970^{*}(0$. & 49) & -0.1 & $72(0.865)$ \\
\hline & Gen & $\mathrm{X}$ & $\mathrm{Ge}$ & & & $\mathbf{X}$ & Ger & & &. $\mathrm{X}$ & Ge & $\mathrm{Z}$ \\
\hline & & $91^{* *}$ & 0.0 & & & 443 & $(0.01$ & & & 530 & 0.120 & \\
\hline
\end{tabular}


INTERNATIONAL JOURNAL OF ENTREPRENEURIAL KNOWLEDGE

Issue 9, volume 2, ISSN 2336-2960 (Online)

www.ijek.org

Note: T.A. - Type of answer; ${ }^{*} \alpha=5 \%{ }^{* *} \alpha=1 \% ;{ }^{* * *} \alpha=0.1 \%$; Ch.S.- Chi-square test.

(Source: Own data collection)

The results (see tab. 7) confirm that there are statistically significant differences between generations (X, $\mathrm{Y}, \mathrm{Z})$ in the perception of the legal risk sources (RS13: $\mathrm{p}$-value $=0.000 ; \mathrm{RS14}$ : $\mathrm{p}$-value $=0.003$; RS15: $\mathrm{p}$ value $=0.015)$. Also, there are statistically significant differences in positive answers between generations: $\mathrm{X}-\mathrm{Z}(\mathrm{RS13}$ : $\mathrm{p}$-value $=0.002 ; \mathrm{RS14}: \mathrm{p}$-value $=0.015)$ and $\mathrm{X}-\mathrm{Y}(\mathrm{RS15}: \mathrm{p}$ - value $=0.049)$. Hypothesis H5 was confirmed.

\subsection{Evaluation of operational risk sources}

The Structure of the respondents' attitudes ( $\mathrm{n}=1585$; operational risk sources - RS16, RS17, RS18) were: RS16: A1+A2 - 1066 (67.3\%), A3 - 354 (23.0\%), A4+A5 - 155 (9.7\%); RS17: A1+A2 - 1009 (63.7\%), A3 - 423 (26.7\%), A4+A5 - 153 (9.6\%); RS18: A1+A2 - 860 (54.3\%), A3 - 393 (24.8\%), A $4+\mathrm{A} 5-332(20.9 \%)$. Table 8 showed the evaluation of operational risk sources according to the age of respondent.

Table 8 The attitudes of respondents on the operational risk sources

\begin{tabular}{|c|c|c|c|c|c|c|c|c|c|c|c|c|}
\hline \multirow[b]{2}{*}{ T. A. } & \multicolumn{4}{|c|}{ RS16 } & \multicolumn{4}{|c|}{ RS17 } & \multicolumn{4}{|c|}{ RS18 } \\
\hline & Gen. $\mathrm{Z}$ & \multicolumn{2}{|c|}{ Gen. Y } & $\begin{array}{c}\text { Gen. } \\
\text { X }\end{array}$ & Gen. $\mathrm{Z}$ & \multicolumn{2}{|c|}{ Gen. Y } & $\begin{array}{c}\text { Gen. } \\
\text { X }\end{array}$ & Gen. $\mathrm{Z}$ & \multicolumn{2}{|c|}{ Gen. Y } & Gen. $\mathbf{X}$ \\
\hline A1 & 70 & \multicolumn{2}{|c|}{74} & 146 & 94 & \multicolumn{2}{|c|}{91} & 168 & 72 & \multicolumn{2}{|c|}{90} & 232 \\
\hline A2 & 141 & \multicolumn{2}{|c|}{224} & 411 & 115 & \multicolumn{2}{|c|}{203} & 338 & 81 & \multicolumn{2}{|c|}{125} & 260 \\
\hline $\begin{array}{c}\mathbf{A} 1+\mathbf{A} \\
2 \\
\%\end{array}$ & $\begin{array}{c}211 \\
(67.6)\end{array}$ & \multicolumn{2}{|c|}{$\begin{array}{c}298 \\
(62.7)\end{array}$} & $\begin{array}{c}557 \\
(69.8)\end{array}$ & $\begin{array}{c}209 \\
(67.0)\end{array}$ & \multicolumn{2}{|c|}{$\begin{array}{c}294 \\
(61.9)\end{array}$} & $\begin{array}{c}506 \\
(63.4)\end{array}$ & $\begin{array}{c}153 \\
(49.0)\end{array}$ & \multicolumn{2}{|c|}{$\begin{array}{c}215 \\
(45.3)\end{array}$} & $\begin{array}{c}492 \\
(61.7)\end{array}$ \\
\hline A3 & 71 & \multicolumn{2}{|c|}{119} & 174 & 66 & \multicolumn{2}{|c|}{133} & 224 & 70 & \multicolumn{2}{|c|}{114} & 209 \\
\hline A4 & 25 & \multicolumn{2}{|c|}{53} & 55 & 25 & \multicolumn{2}{|c|}{40} & 51 & 56 & \multicolumn{2}{|c|}{94} & 69 \\
\hline A5 & 5 & \multicolumn{2}{|c|}{5} & 12 & 12 & \multicolumn{2}{|c|}{8} & 17 & 33 & \multicolumn{2}{|c|}{52} & 28 \\
\hline $\begin{array}{l}\text { Chi. } \\
\text { S. }\end{array}$ & \multicolumn{4}{|c|}{$15.577^{*}(0.049)$} & \multicolumn{4}{|c|}{$24.762^{* *}(0.006)$} & \multicolumn{4}{|c|}{$80.907^{* * *}(0.000)$} \\
\hline $\begin{array}{l}\text { Z- } \\
\text { Score }\end{array}$ & \multicolumn{2}{|c|}{$\begin{array}{c}\text { Gen.X/Gen } \\
\text {.Y }\end{array}$} & \multicolumn{2}{|c|}{$\begin{array}{c}\text { Gen.Y/Gen } \\
. Z \\
\end{array}$} & \multicolumn{2}{|c|}{$\begin{array}{c}\text { Gen.X/Gen } \\
\text {.Y }\end{array}$} & \multicolumn{2}{|c|}{$\begin{array}{c}\text { Gen.Y/Gen } \\
. \mathrm{Z} \\
\end{array}$} & \multicolumn{2}{|c|}{$\begin{array}{c}\text { Gen.X/Gen } \\
\text {.Y }\end{array}$} & \multicolumn{2}{|c|}{$\begin{array}{c}\text { Gen.Y/Gen } \\
. Z\end{array}$} \\
\hline $\begin{array}{c}\mathbf{A} 1+\mathbf{A} \\
\quad 2\end{array}$ & \multicolumn{2}{|c|}{$2.595(0.009)$} & \multicolumn{2}{|c|}{$-1.404(0.161)$} & $0.540(0$. & & -1.4 & $5(0.144)$ & $\begin{array}{c}5.692^{* * *} \\
)\end{array}$ & & -1.0 & $40(0.298)$ \\
\hline$(\mathrm{p}-$ & Ger & $\mathbf{X}$ & Ger & & & . $\mathrm{X}$ & Ger & & &. $\mathrm{X}$ & $\mathrm{Ge}_{1}$ & \\
\hline val.) & & 704 & 0.484 & & & .120 & 0.263 & & & 30 & $(0.00$ & \\
\hline
\end{tabular}

Note: T.A. - Type of answer; ${ }^{*} \alpha=5 \% ;{ }^{* *} \alpha=1 \% ;{ }^{* * *} \alpha=0.1 \%$; Ch.S.- Chi-square test.

(Source: Own data collection)

The results (see tab. 8) confirm that there are statistically significant differences between generations $(\mathrm{X}$, $\mathrm{Y}, \mathrm{Z}$ ) in the perception of the operational risk sources (RS16: $\mathrm{p}$-value $=0.049 ; \mathrm{RS17}$ : $\mathrm{p}$-value $=0.006$; RS18: $\mathrm{p}$-value $=0.000)$. Also, there are statistically significant differences in positive answers between generations: X-Y (RS16: $\mathrm{p}$-value $=0.009$; RS18: $\mathrm{p}$-value $=0.000)$ and X-Z (RS18: $\mathrm{p}$ - value $=0.000$ ). Hypothesis $H 6$ was confirmed. All results according to the Chi-square tests were verified non-parametric approach (by Kruskal-Wallis tests) with the same evaluation of hypotheses. 
INTERNATIONAL JOURNAL OF ENTREPRENEURIAL KNOWLEDGE

Issue 9, volume 2, ISSN 2336-2960 (Online)

www.ijek.org

\section{DISCUSSION}

Key findings of the case study:

- Generation X (69.8\%) applies a participative management style (involving employees in decision making) more often than generation $\mathrm{Y}(63.8 \%)$ and generation $\mathrm{Z}(62.5 \%)$.

- Generation Z (55.4\%) uses innovative ways to win new markets and retain existing customers in the SME more often than generation Y $(51.2 \%)$ and generation $X(47.6 \%)$.

- Generation X (78.5\%) considers financial risk as part of everyday business at a greater level than generation $\mathrm{Z}(71.5 \%)$ and generation $\mathrm{Y}(70.5 \%)$.

- Generation Y (51.4\%) in the least level thinks that the error rate of employees is low and has no negative impact on the SME than generation X (60.3\%) and generation Z (60.6\%). Generation Z $(58.3 \%)$ considers that the personnel risk is adequate in the SME and does not harm business at a greater level than generation X $(51.0 \%)$ and generation Y $(49.9 \%)$.

- Generation X (40.7\%) in the least level consider the legal risk-appropriate and does not harm respondent's business than generation Z (51.0\%). Generation X $(27.2 \%)$ in the least level do not consider the business environment to be 'over-regulated' than generation $Z(34.6 \%)$.

- Generation X (61.7\%) thinks that the number of possible requests for specific products/services has a downward trend at the greater level than generation Z (49.0\%) and generation Y (45.3\%).

The results agree with the findings of Wasilczuk \& Richert-Kaźmierska (2020), which found significant differences in the perception of business risks and in the business orientation between generations $\mathrm{Y}$ and Z.

\section{CONCLUSIONS}

This article aimed to identify common features, disparities, and consequences in the perception of business risks between generation $\mathrm{X}, \mathrm{Y}$, and $\mathrm{Z}$ entrepreneurs in the segment of small and medium-sized enterprises.

The research results prove the existence of the significant disparities in the perception of the market, financial, personnel, legal, and operational risks sources by the entrepreneurs from $\mathrm{X}, \mathrm{Y}$, and $\mathrm{Z}$ generations. In addition, generation $X$ perceives the sources of legal risk more negatively than Generation $\mathrm{Y}$ and $\mathrm{Z}$. Generation $\mathrm{X}$ better manages operational risk than generation $\mathrm{Y}$ and $\mathrm{Z}$. The perception of the personnel and legal risk sources reveal the most significant disparities between generations $(\mathrm{X}, \mathrm{Y}, \mathrm{Z})$.

The findings are essential for the business environment of the Visegrad Group countries (Czech Republic, Slovak Republic, Hungary, and Poland) focused on the segment of small and medium-sized enterprises. However, this research has certain limitations related to the data collection period. For example, the data collection took place before and during the first months of the coronavirus pandemic when the SME segment had not already perceived the adverse effects associated with the COVID-19 pandemic. Furthermore, the subjectivity of the owners' and top managers' responses is often inconsistent and determined by the company's financial performance.

The article's findings are of some benefit to the owners and top managers in small and medium-sized enterprises. They are the ones who make decisions and communicate on a daily basis with their employees, suppliers, customers. The knowledge of the differences between generations of entrepreneurs contributes to the improvement of interpersonal and labor relations. It is equally essential to bring case studies from primary research for national policymakers in the SME segment to create more targeted 


\section{INTERNATIONAL JOURNAL OF ENTREPRENEURIAL KNOWLEDGE}

Issue 9, volume 2, ISSN 2336-2960 (Online)

www.ijek.org

support (economic, educational, etc.). Organizations and associations that focus on supporting the business environment in the SME segment in selected research countries are also the potential recipients of the findings.

The case study analyzes and quantifies different perceptions of business risks only concerning the respondent's age. By examining other demographic characteristics of the respondent, such as gender, level of education, or the link between the level of education and the focus of SMEs, could be the following research direction.

\section{REFERENCES}

Adamopoulou, E., Bobbio, E., De Philippis, M., \& Giorgi, F. (2016). Wage rigidities and business cycle fluctuations: A linked employer-employee analysis. IZA Journal of Labor Policy, 5(1) https://doi.org/10.1186/s40173-016-0078-5

Afsar, B., \& Badir, Y. F. (2016). Person-organization fit, perceived organizational support, and organizational citizenship behavior: The role of job embeddedness. Journal of Human Resources in Hospitality and Tourism, 15(3), 252-278. https://doi.org/10.1080/15332845.2016.1147936

Al-Haddad, L., Sial, M. S., Ali, I., Alam, R., Khuong, N. V., \& Khanh, T. H. T. (2019). The role of small and medium enterprises (SMEs) in employment generation and economic growth: A study of marble industry in emerging economy. International Journal of Financial Research, 10(6), 174-187. https://doi.org/10.5430/ijfr.v10n6p174

Allee, K. D., \& Yohn, T. L. (2009). The demand for financial statements in an unregulated environment: An examination of the production and use of financial statements by privately held small businesses. Accounting Review, 84(1), 1-25. https://doi.org/10.2308/accr.2009.84.1.1

Alnoor, A. (2020). Human capital dimensions and firm performance, mediating role of knowledge management. International Journal of Business Excellence, 20(2), 149-168. https://doi.org/10.1504/IJBEX.2020.105357

Aktas, N., De Bodt, E., Bollaert, H., \& Roll, R. (2016). CEO narcissism and the takeover process: From private initiation to deal completion. Journal of Financial and Quantitative Analysis, 51(1), 113-137. https://doi.org/10.1017/S0022109016000065

Aparicio, S., Urbano, D., \& Audretsch, D. (2016). Institutional factors, opportunity entrepreneurship and economic growth: Panel data evidence. Technological Forecasting and Social Change, 102, 45-61. https://doi.org/10.1016/j.techfore.2015.04.006

Baños-Caballero, S., García-Teruel, P. J., \& Martínez-Solano, P. (2016). Financing of working capital requirement, financial flexibility and SME performance. Journal of Business Economics and Management, 17(6), 1189-1204. https://doi.org/10.3846/16111699.2015.1081272

Barbosa, M., Castañeda -Ayarza, J. A., \& Lombardo Ferreira, D. H. (2020). Sustainable strategic management (GES): Sustainability in small business. Journal of Cleaner Production, 258 https://doi.org/10.1016/j.jclepro.2020.120880

Bayaga, A., \& Flowerday, S. (2010). A conceptual operational risk model for SMEs: Impact on organisational information technology. Paper presented at the Proceedings of the 2010 Information Security for South Africa Conference, ISSA 2010, https://doi.org/10.1109/ISSA.2010.5588329

Beck, T., \& Demirguc-Kunt, A. (2006). Small and medium-size enterprises: Access to finance as a growth constraint. Journal of Banking and Finance, 30(11), 2931-2943. https://doi.org/10.1016/j.jbankfin.2006.05.009

Becker, K., \& Smidt, M. (2016). A risk perspective on human resource management: A review and directions for future research. Human Resource Management Review, 26(2), 149-165. https://doi.org/10.1016/j.hrmr.2015.12.001

Belot, F., \& Serve, S. (2018). Earnings quality in private SMEs: Do CEO demographics matter? Journal of Small Business Management, 56, 323-344. https://doi.org/10.1111/jsbm.12375 


\section{INTERNATIONAL JOURNAL OF ENTREPRENEURIAL KNOWLEDGE}

Issue 9, volume 2, ISSN 2336-2960 (Online)

www.ijek.org

Bosma, N., Content, J., Sanders, M., \& Stam, E. (2018). Institutions, entrepreneurship, and economic growth in europe. Small Business Economics, 51(2), 483-499. https://doi.org/10.1007/s11187-0180012-x

Betáková, J., Okręglicka, M., \& Havierniková, K. (2021). Entrepreneurial orientation of male and female entrepreneurs in small firms. TEM Journal, 10(3), 1307-1313. https://doi.org/10.18421/TEM10338

Brunswicker, S., \& Vanhaverbeke, W. (2015). Open innovation in small and medium-sized enterprises (SMEs): External knowledge sourcing strategies and internal organizational facilitators. Journal of Small Business Management, 53(4), 1241-1263. https://doi.org/10.1111/jsbm.12120

Crovini, C., Ossola, G., \& Britzelmaier, B. (2021). How to reconsider risk management in SMEs? an advanced, reasoned and organised literature review. European Management Journal, 39(1), 118-134. https://doi.org/10.1016/j.emj.2020.11.002

Deckop, J. R., Cirka, C. C., \& Andersson, L. M. (2003). Doing unto others: The reciprocity of helping behavior in organizations. Journal of Business Ethics, 47(2), 101-113. https://doi.org/10.1023/A:1026060419167

De Clercq, D., Dimov, D., \& Thongpapanl, N. T. (2013). Organizational social capital, formalization, and internal knowledge sharing in entrepreneurial orientation formation. Entrepreneurship: Theory and Practice, 37(3), 505-537. https://doi.org/10.1111/etap.12021

Deligonul, S. Z. (2020). Multinational country risk: Exposure to asset holding risk and operating risk in international business. Journal of World Business, 55(2). https://doi.org/10.1016/j.jwb.2019.101041

Doran, J., Mccarthy, N., \& O'connor, M. (2019). The importance of internal knowledge generation and external knowledge sourcing for sme innovation and performance: Evidence from ireland. International Journal of Innovation Management, 23(7). https://doi.org/10.1142/S1363919619500695

Dvorský, J., Petráková, Z., Fialová, V. (2020). Perception of Business Risks by Entrepreneurs According to Experience with the Business Failure. International Journal of Entrepreneurial Knowledge, 8 (1), 76-88. https:/ / doi.org/10.37335 / ijek.v8i1.104

El Shoubaki, A., Laguir, I., \& den Besten, M. (2020). Human capital and SME growth: The mediating role of reasons to start a business. Small Business Economics, 54(4), 1107-1121. https://doi.org/10.1007/s11187-018-0129-y

Fernández-Gámez, M. Á., Soria, J. A. C., Santos, J. A. C., \& Alaminos, D. (2020). European country heterogeneity in financial distress prediction: An empirical analysis with macroeconomic and regulatory factors. Economic Modelling, 88 ,

398-407. https://doi.org/10.1016/j.econmod.2019.09.050

Frantz, E., Dugan, A., Hinchberger, K., Maseth, B., Al Sharfa, O., \& Al-Jaroodi, J. (2017). SMEs: The effects of strategic management. IEEE Technology and Engineering Management Society Conference, 388393. https://doi.org/10.1109/TEMSCON.2017.7998406

Fuertes, G., Alfaro, M., Vargas, M., Gutierrez, S., Ternero, R., \& Sabattin, J. (2020). Conceptual framework for the strategic management: A literature review - descriptive. Journal of Engineering (United Kingdom), https://doi.org/10.1155/2020/6253013

Games, D., \& Roliza, R. (2019). SME Internal Capability and Competitive Advantage in an Emerging Market: Moderating Effects of Firm Age. Andalas Management Review, 3(1), 103-114. https://doi.org/10.25077/amar.3.1.103-114.2019

Gede Riana, I., Suparna, G., Gusti Made, I., Kot, S., \& Rajiani, I. (2020). Human resource management in promoting innovation and organizational performance. Problems and Perspectives in Management, 18(1), 107-118. https://doi.org/10.21511/ppm.18(1).2020.10

Grau, A., \& Reig, A. (2021). Operating leverage and profitability of SMEs: Agri-food industry in europe. Small Business Economics, 57(1), 221-242. https://doi.org/10.1007/s11187-019-00294-y

Gwizdala, J. P. (2017). The Financing of Small and Medium-Sized Enterprises with the EU Structural Funds in Poland Between 2014 and 2020. International Journal of Synergy and Research, 6, 4355. https://doi.org/10.17951/ijsr.2017.6.43 


\section{INTERNATIONAL JOURNAL OF ENTREPRENEURIAL KNOWLEDGE}

Issue 9, volume 2, ISSN 2336-2960 (Online)

www.ijek.org

Herath, H. M. A., \& Mahmood, R. (2014). Strategic orientations and SME performance: Moderating effect of absorptive capacity of the firm. Asian Social Science, 10(13), 95-107. https://doi.org/10.5539/ass.v10n13p95

Hock-Doepgen, M., Clauss, T., Kraus, S., \& Cheng, C. -. (2021). Knowledge management capabilities and organizational risk-taking for business model innovation in SMEs. Journal of Business Research, 130, 683-697. https://doi.org/10.1016/j.jbusres.2019.12.001

Hubner, S., Rudic, B., \& Baum, M. (2021). How entrepreneur's leadership behavior and demographics shape applicant attraction to new ventures: The role of stereotypes. International Journal of Human Resource Management, https://doi.org/10.1080/09585192.2021.1893785

Hvolkova, L., Klement, L., Klementova, V., \& Kovalova, M. (2019). Barriers Hindering Innovations in Small and Medium-Sized Enterprises. Journal of Competitiveness, 11(2), 51-67. https://doi.org/10.7441/ joc.2019.02.04

Kersten, R., Harms, J., Liket, K., \& Maas, K. (2017). Small firms, large impact? A systematic review of the SME finance literature. World Development, 97, 330-348. https://doi.org/10.1016/j.worlddev.2017.04.012

Konstantopoulou, A., Rizomyliotis, I., Konstantoulaki, K., \& Badahdah, R. (2019). Improving SMEs' competitiveness with the use of instagram influencer advertising and eWOM. International Journal of Organizational Analysis, 27(2), 308-321. https://doi.org/10.1108/IJOA-04-2018-1406

Mai, A. N., Vu, H. V., Bui, B. X., \& Tran, T. Q. (2019). The lasting effects of innovation on firm profitability: Panel evidence from a transitional economy. Economic Research-Ekonomska Istrazivanja, 32(1), 3411-3430. https://doi.org/10.1080/1331677X.2019.1660199

Malega, P., Rudy, V., Kovac, J., \& Kovac, J. (2019). The Competitive Market Map as the Basis for an Evaluation of the Competitiveness of the Slovak Republic on an International Scale. Journal of Competitiveness, 11(4), 103-119. https://doi.org/10.7441/joc.2019.04.07

Mättö, M., \& Niskanen, M. (2021). Role of the legal and financial environments in determining the efficiency of working capital management in european SMEs. International Journal of Finance and Economics, 26(4), 5197-5216. https://doi.org/10.1002/ijfe.2061

Mura, L., Ključnikov, A., Tvaronavičienè, M., \& Androniceanu, A. (2017). Development trends in human resource management in small and medium enterprises in the visegrad group. Acta Polytechnica Hungarica, 14(7), 105-122. https://doi.org/10.12700/APH.14.7.2017.7.7

Neuberger, D., \& Räthke-Döppner, S. (2015). The role of demographics in small business loan pricing. Small Business Economics, 44(2), 411-424. https:/ / doi.org/10.1007/s11187-014-9602-4

Pereira, L., Tenera, A., Bispo, J., \& Wemans, J. (2015). A risk diagnosing methodology web-based platform for micro, small and medium businesses: Remarks and enhancements. Conference on Knowledge Discovery, Knowledge Engineering and Knowledge Management. https://doi.org/10.1007/978-3662-46549-3_22

Pisar, P., \& Bilkova, D. (2019). Controlling as a tool for SME management with an emphasis on innovations in the context of Industry 4.0. Equilibrium. Quarterly Journal of Economics and Economic Policy, 14(4), 763-785. https://doi.org/10.24136/eq.2019.035

Prijadi, R., Wulandari, P., Desiana, P. M., Pinagara, F. A., \& Novita, M. (2020). Financing needs of microenterprises along their evolution. International Journal of Ethics and Systems, 36(2), 263-284. https://doi.org/10.1108/IJOES-05-2018-0071

Rahman, A., Rozsa, Z., Cepel, M. (2018). Trade Credit and Bank Finance - Evidence from the Visegrad Group. Journal of Competitiveness, 10(3), 132-148. https://doi.org/10.7441/joc.2018.03.09

Ravselj, D. \& Aristovnik, A. (2018). Administrative barriers for SMEs in the field of tax compliance and financial and accounting reporting: Evidence from Slovenia. Management Issues, 16(1(73)), 75-90. https://doi.org/10.7172/1644-9584.73.5

Redmond, J., \& Sharafizad, J. (2020). Discretionary effort of regional hospitality small business employees: Impact of non-monetary work factors. International Journal of Hospitality Management, 86 https://doi.org/10.1016/j.ijhm.2020.102452 
INTERNATIONAL JOURNAL OF ENTREPRENEURIAL KNOWLEDGE

Issue 9, volume 2, ISSN 2336-2960 (Online)

www.ijek.org

Reverte, C. (2015). The new spanish corporate social responsibility strategy 2014-2020: A crucial step forward with new challenges ahead. Journal of Cleaner Production, 91, 327-336. https://doi.org/10.1016/j.jclepro.2014.12.041

Sánchez-Ballesta, J. P., \& Yagüe, J. (2021). Financial reporting incentives, earnings management, and tax avoidance in SMEs. Journal of Business Finance and Accounting, 48(7-8), 1404-1433. https://doi.org/10.1111/jbfa.12519

Santa, M., Stojkoski, V., Josimovski, M., Trpevski, I., Kocarev, L. (2019). Robust determinants of companies' capacity to innovate: A bayesian model averaging approach. Tecbnology Analysis and Strategic Management, 31(11), 1283-1296. https:/ / doi.org/10.1080/09537325.2019.1605052

Virglerova, Z., Dvorsky, J., Kozubikova, L., \& Cepel, M. (2020). Perception of non-financial risk determinants in SMEs in visegrad countries. Oeconomia Copernicana, 11(3), 509-529. https://doi.org/10.24136/OC.2020.021

Wach, K., \& Głodowska, A. (2021). How do demographics and basic traits of an entrepreneur impact the internationalization of firms? Oeconomia Copernicana, 12(2), 399-424. https://doi.org/10.24136/OC.2021.014

Wang, Y. (2016). What are the biggest obstacles to growth of SMEs in developing countries? - an empirical evidence from an enterprise survey. Borsa Istanbul Review, 16(3), 167-176. https://doi.org/10.1016/j.bir.2016.06.001

Wasilczuk, J. E., \& Richert-Kaźmierska, A. (2020). What potential entrepreneurs from generation y and $\mathrm{z}$ lack-ieo and the role of EE. Education Sciences, 10(11), 1-14. https://doi.org/10.3390/educsci10110331

Yang, J. S. (2017). The governance environment and innovative SMEs. Small Business Economics, 48(3), 525-541. https://doi.org/10.1007/s11187-016-9802-1

Zsigmond, T., Machová, R., \& Zsigmondová, A. (2021). Strategic management from the perspective of SMEs operating in service sector. Quality Innovation Prosperity, 25(2), 37-53. https://doi.org/10.12776/qip.v25i2.1549

\section{BRIEF DESCRIPTION OF AUTHOR/AUTHORS:}

Assoc. Prof. Ing. Zora Petráková, PhD.

ORCID ID: https://orcid.org/0000-0002-1398-9415

Affiliation: Institute for Forensic Engineering, Faculty of Civil Engineering, Slovak University of Technology, Radlinského 11, 81005 Bratislava, Slovak Republic, Affiliation web page: www.svf.stuba.sk Email: zora.petrakova@stuba.sk.

She is head of the Institute for Forensic Engineering. She provides lectures in Forensic and economic engineering for full-time students. He published 4 scientific articles on database Scopus $(\mathrm{h}$-index $=2)$ and 3 scientific articles on database Web of Science $(\mathrm{h}$-index $=2)$.

\section{Karolina Okręglicka, BA.}

Affiliation: Czestochowa University of Technology, Faculty of Management, Dabrowskiego 69, 42-201, Czestochowa, Poland

Email:ka.okreglicka@gmail.com

She is a student at the Faculty of Management, Czestochowa University of Technology in Poland. Her research interest is focused on entrepreneurship, SMEs, and corporate management.

PhDr. Ing. Radim Maňák, Ph.D.

Affiliation: The University of Entrepreneurship and Law, Department of Entrepreneurship and Management, Michálkovická 1810/181, $710 \quad 00$ Ostrava, Czech Republic, website: https:/ /is.vspp.cz/lide/clovek.pl?id=20074 
INTERNATIONAL JOURNAL OF ENTREPRENEURIAL KNOWLEDGE

Issue 9, volume 2, ISSN 2336-2960 (Online)

www.ijek.org

Email: radim.manak@vspp.cz

His main research areas are measuring employees 'performance and tools of business ethics and their application in companies. His teaching activities include the following courses: Human Resource Management, Business Ethics, Manager of Human Potential, Labor Market, and German Language. He published one scientific article indexed in Scopus and four scientific articles indexed in the Web of Science database $(\mathrm{h}$-index $=1)$.

\section{Ing. Vendula Fialová, Ph.D.}

ORCID ID: https://orcid.org/0000-0002-2368-0243

Affiliation: The University of Entrepreneurship and Law, Department of Entrepreneurship and Management, Michálkovická 1810/181, 71000 Ostrava, Czech Republic, website: https:/ /is.vspp.cz/lide/clovek.pl?id=20199;

Email: vendula.fialova@vspp.cz

Her research is focused on Small and Medium-sized Enterprises, Entrepreneurship, Business Environment, and Family businesses. She published one scientific article indexed in Scopus, three scientific articles, and five conference papers indexed in the Web of Science. 